\title{
The Effect of External Factors on the Sustainability of Msme Business in Medan City During Covid 19 Pandemy
}

\author{
Rina Walmiaty Mardi* \\ Banking Study Program \\ Politeknik Negeri Medan (POLMED) \\ Medan, Indonesia \\ *rinamardi@polmed.ac.id
}

\author{
Indra Siregar \\ MICE Study Program \\ Politeknik Negeri Medan (POLMED) \\ Medan, Indonesia \\ indra.siregar@polmed.ac.id
}

\begin{abstract}
The purpose of this study is to determine how the influence of external factors in the form of market access, business climate and financial limitations in Medan City on business continuity during the COVID 19 pandemic. The Indonesian economy is the economy of MSMEs because it contributes more than $60 \%$ of Indonesia's GDP, $70 \%$ of all businesses in Indonesia come from MSMEs. Quantitative descriptive research method used in this study by providing interviews and questions based on indicators on the independent and dependent variables. The MSME studied were culinary, travel and convection businesses that received credit and were not in banking financing. The result of the research is that the influence of external factors on business continuity in MSMEs, namely the business climate factor, limited market access and financial limitations, affect the business continuity of MSMEs in the Travel and Convection sector. Meanwhile, in the culinary sector, they are able to anticipate the limitations that exist due to the Covid 19 pandemic by changing their marketing strategies. Therefore the government must take policies that can support the Travel and Convection sector MSMEs to continue their business.
\end{abstract}

Keywords-External factors, MSMEs, business continuity and pandemic

\section{INTRODUCTION}

Currently, the development of MSMEs in Indonesia has progressed. Likewise, there are several factors that hinder the development of MSMEs. On internal factors, Gunartin [1] states that there are still limited human resources (HR) and product marketing constraints where most small industry entrepreneurs prioritize production aspects. On external factors, Ariani [2] says there are constraints on the business climate, limitations facilities and infrastructure, the impact of regional autonomy, the impact of free markets, limited market access, limited human resources, financial limitations. From research conducted by Suandi and Susilo [3], Sakur [4], and Irdayanti [5], it was found that the weak competitiveness of MSMEs was caused by several problems, including: marketing, capital and funding, innovation and utilization of information technology, use of raw materials, production equipment, absorption and empowerment of labor, business development plans, and readiness. facing external environmental challenges. At the moment, the impact of the COVID-19 pandemic includes external factors faced by MSMEs and this has a very real effect on the economy of MSMEs, Tourism, and Manufacturing. Quoted from CNN Indonesia, the Minister of Finance of the Republic of Indonesia said that Indonesia's economic growth projection will only reach $2.3 \%$. Even in the worst conditions the economy can go down to minus $0.4 \%$. The cause is the decline in consumption and investment, both within the household sphere and the government sphere. MSME, Tourism, Manufacturing. The tourism sector reported from coverage 6 , world travel and tourism predicts that there will be 75 million workers in the travel and tourism industry who can lose their jobs. The manufacturing world, which normally boosts industry due to increased public demand, is currently decreasing its production. Daily employees are asked to take turns off, so that their income is halved if they are fully laid off. Employees also lost their jobs due to reduced processing, imports of raw materials also decreased. The final result of the manufacturing process will also experience a decline in exports due to lower demand from abroad. This situation was conveyed by the Chairman of the Indonesian MSME Association, Mr. Ikhsan Ingatubun in April 2020. Physical distancing set by the local government keeps people at home and do not leave the house for activities as usual.

For MSMEs, with the physical distancing due to this pandemic, they cannot carry out business activities. Based on data from Dinas Koperasi Kota Medan in May 2020, as many as 672,000 MSMEs in Medan were affected by the corona pandemic Because of this, they experience difficulties in paying existing costs such as salaries, employee salaries, and other operational and non-operational costs. This has a bad impact if workers cannot make money. They are forced to return home to survive because they do not have enough income to live in overseas areas.

Some of the previous studies related to this theme are: 1 . Andi Amri, Hasanuddin University, with the title of research: The impact of COVID-19 on MSMEs in Indonesia 2. Wan Laura Hardilawati, Muhammadiyah Riau university, with the 
title of research: The Survival Strategi of MSME during The Covid 19 Pandemic 3. Aknolt Kristian Pakpahan, Parahyangan University, with the title of research: COVID-19 and its implications for MSMEs. The novelty of our research is research conducted specifically for MSME in Medan which is focused on the travel, convection and culinary industries [6-8].

According to Belkoui [9] going concern is an argument which states that a business entity will continue its operations for a long enough time to realize its projects, responsibilities and activities that do not stop. Arens in Wahyuningsih [10] states several factors that cause uncertainty regarding the survival of the company are: 1. Large business losses repeatedly or lack of working capital. 2. The company's inability to pay its obligations at maturity in the short term. 3 . Losing major customers due to uninsured disasters such as earthquakes, floods or labor problems. 4. Lawsuits, lawsuits or similar issues that have occurred which could jeopardize the company's ability to operate.

The application of e-business in a business organization (company) can actually lead to two alternative outcomes, namely profitable and detrimental to the company concerned. What is meant by marketing is a social and managerial process in which individuals and groups get their needs and desires by creating, offering and exchanging products that are valuable to others [11]. Companies in marketing their products need to design and disseminate information about their presence, availability, product characteristics and product conditions as well as the benefits that customers / potential customers can get for the products offered by the company [12]. E-business is very profitable both in terms of product sales, very broad promotion and efficiency in the use of labor, while on the other hand it can be detrimental because the operational costs required to procure technology are very high [13]. Vandeim [14] argues that the demands of globalization, digitization and the level of competition between companies in providing quality and timely products or services as well as price advantages or product or service differentiation make companies have to use information technology or e-business as one of the technologies that can provide convenience. coordination between business functions.

In the midst of the development of MSMEs that were not too good in early 2020, Indonesia, especially the MSME sector, was again tested with the emergence of the Covid 19 outbreak. The government in Indonesia has tried various lockdown efforts so that social distancing occurs. The impact of this lockdown is definitely there and has a very direct impact on the economic downturn, especially the MSME economy. As a result of the lockdown, MSMEs were hampered by sales and production processes.

As the third largest city in Indonesia, Medan is certainly feeling the impact of this corona pandemic. Although the locked down policy did not apply, the large-scale restrictions imposed by the Medan city government on a large enough scale resulted in greatly reduced activities in the city of Medan, including activities in the economic sector. The policy to limit the movement of people to and from the city of Medan has been enforced quite strictly since March 2020. Therefore, researchers feel the need to examine how this condition affects the business conditions of MSMEs in the city of Medan.

\section{MethodS}

\section{A. Formulation of The Problem}

The formulation of the problem from this research is How are the Effects of External Factors on the Business Continuity of Medan City MSMEs during the COVID-19 Pandemic?

\section{B. Scope of Problem}

The limitation in this research is external factors. MSME (Micro, Small and Medium Enterprises) which are the objects of this research are culinary, travel and convection businesses located in Medan City.

\section{Research Methods}

This research was conducted with a qualitative descriptive method. Data was collected through interviews with MSMEs in the culinary, travel and convection sectors whose business offices domicile in the city of Medan. The subjects of this study were chosen because based on initial interviews with MSME actors it was known that these three sectors were most affected by the corona pandemic.

Research design, used a questionnaire containing several items of questions regarding indicators of business continuity and also conducted interviews as a follow-up to giving questionnaires to make the results more accurate. The question indicator will be made on an ordinal scale of 0,1 and a Likert scale $(1,2,3,4,5)$.

1. Business performance in the form of financial reports before and after the pandemic. (Likert scale). 2. Monthly sales before and after the pandemic (Likert scale). 3. Number of orders before and after the pandemic (Likert scale). 4. Use of credit or non-credit (dummy variable).

The questionnaire was distributed by researchers as many as 90 samples. Which consists of 30 for the culinary business, 30 for the travel business and 30 for the convection business. All of the questionnaires returned were because they were escorted directly by the researcher until they finished filling out and interviewing.

The analysis was carried out by performing multiple linear regression using the SPSS application.

\section{RESULTS}

Based on observations, these three fields of MSMEs have felt a very real impact since the outbreak of the corona outbreak, especially in the city of Medan. Large-scale restrictions on human movement have caused residents of Medan to comply with the government's appeal to always stay at home. This has caused the turnover of MSMEs to experience 
a deep contraction since the Covid 19 pandemic hit Indonesia starting in March 2020.

However, based on interviews with MSME people in these three fields in Medan, there is a considerable difference between the three fields in overcoming the effects of this corona pandemic even though the steps they are taking are relatively the same. The things that have been done by Medan City MSMEs in dealing with the corona pandemic are as follows:

\section{A. E-Commerce}

E-commerce is a process of buying and selling products that are carried out electronically by consumers and from company to company with computers as an intermediary for business transactions [15]. E-commerce, which was originally an online retail sales mechanism, has now created a new digital market with more transparent prices, easy access, a global market with highly efficient warehousing. With this ecommerce, business people can easily do product marketing or adopt methods that are done by other business actors in terms of marketing.

The results of interviews with business actors in the three MSME fields in Medan City are as follows:

1) Travel agent: For business people in the Travel Agent field, there is no strategy that can be done to overcome the impact of this corona pandemic. The essence of the travel agent business is to facilitate the movement of people from one place to another, automatically completely paralyzed because human movement is almost non-existent. Health protocols that severely limit movement and interaction between residents make the services provided by the Travel Agent unusable. Sales via e-commerce cannot help Travel Agents continue to run their business in the midst of this Corona Pandemic. When the corona pandemic occurred, all travel agents in Medan closed their businesses.

2) Convection: Business people in the field of convection Medan City experienced a very significant impact due to the Corona pandemic. The sales turnover of this convection business people remains $30 \%$ compared to the sales turnover before the pandemic occurred. Efforts to sell through ecommerce are carried out by business actors in the convection sector, but are unable to maintain sales levels.

3) Culinary: Culinary business people in Medan City have also experienced the impact of this corona pandemic. To overcome the decline in turnover, culinary business people, especially those providing staple foods, take advantage of marketing through e-commerce to reduce the amount of decline in turnover during the Corona pandemic. Collaboration with Gojek and Grab is a mainstay of Medan's culinary sector in overcoming the impact of the corona. This collaboration is able to increase the number of culinary sales through the culinary platform by around $20 \%$ compared to before the corona pandemic occurred. This is known when conducting interviews with culinary entrepreneurs, whether online sales platforms use GOJEK or GRAB delivery services or help with their sales, the answer given is that sales through GOJEK and GRAB delivery services have increased by about $20 \%$ during the corona pandemic.

\section{B. Digital Marketing}

Digital marketing is a promotional activity and market search through online digital media by utilizing various means, for example social networks [16]. The digital marketing method that is often used by business people is to use social media such as marketing products through Instagram, Facebook, Twitter and others. Besides that, digital marketing can also be done in e-commerce and many other media.

The results of interviews with MSME peoples in the three fields studied regarding digital marketing are as follows:

1) Travel agent: Travel Agents did not carry out any promotions during the Corona pandemic due to the almost non-existent mobility of the population. This is due to health protocols and government policies that restrict population movements to break the chain of spreading the Corona virus so that it does not become more massive in the community. Therefore the Travel Agent practically closes its business when the Corona pandemic is underway while waiting for government policies to loosen the population movement policy.

2) Convection: MSME peoples have used digital marketing platforms even before the corona pandemic hit countries in the world. The pattern of public spending in recent times before the corona pandemic began has shown that digital marketing platforms are very popular with people if they want to shop for convection products, especially finished products such as clothes. This has resulted in many MSME peoples in the field of convection, especially clothing, who do online marketing. When the corona pandemic took place, the level of buyer visits to stores and outlets also drastically decreased. However, it turns out that not only the number of visitors to shops or outlets has decreased, the number of online buyers has also decreased drastically even though digital marketing is increasingly being carried out. This shows that there is a decrease in purchasing power in the community, so that the desire to buy convection products has decreased. Convection products are not a priority, especially during the corona pandemic where people's mobility and gathering activities are very limited.

3) Culinary: For MSME peoples in the culinary field in Medan, when the corona pandemic occurs, they try to be overcome by intensifying marketing through digital marketing. This method was successful in reducing the rate of decline in turnover of MSME entrepreneurs in the culinary field. The necessity to be at home and the closure of various economic centers due to the government's strict restriction policies, causing consumers to use digital information to be 
able to select and order the desired culinary products. So for MSME peoples in the culinary sector, even though they have decreased turnover like other fields, many can maximize digital marketing to be able to increase the number of sales online. Therefore, the decline in turnover of MSME peoples in the culinary field in Medan is not as big as in other fields.

\section{Product Quality Improvement and Services}

The quality of products and services are two things that must be maintained by business actors in order to maintain the trust of their customers. Especially when there is a Corona pandemic like now, the quality of products and services absolutely must be good because the number of consumers is much reduced. MSME peoples must make improvements to product quality to increase consumer confidence and intensively communicate product quality to customers.

As for what is done by MSME actors in the three business fields in this balancing based on the results of the interview are as follows:

1) Travel agent: For MSME peoples in the Travel Agent field in Medan, efforts to improve the quality of products and services cannot be done. This is because at the time of the corona pandemic, the government had almost completely stopped its operation of the transportation service business. Therefore, whatever efforts made by MSME peoples in the Travel Agent sector cannot prevent this business field from terminating operations when the corona pandemic occurs.

2) Convection: MSME peoples in the convection field in the city of Medan are trying to make improvements to the quality of products and services to be able to maintain sales turnover. However, this effort did not work because during the corona pandemic, shopping for convection products was not a priority for the people of Medan City so that efforts to improve the quality of products and services did not succeed in maintaining the turnover of MSME peoples in the convection sector.

3) Culinary: For MSME peoples in the culinary field in Medan City, improving the quality of products and services is quite influential in reducing the decline in turnover caused by this corona pandemic. Consumers want the culinary products produced to be truly hygienic. Therefore, many culinary SMEs in the city of Medan have made improvements to their product packaging. Improving the quality of packaging is carried out to maintain the quality of the culinary products produced in terms of cleanliness and hygiene. As for service, the quality improvement carried out by the culinary sector SMEs in Medan is to ensure that the services provided to customers can be done quickly and guaranteed speed and reliability.

\section{Customer Relationship Marketing (CRM)}

During the current corona pandemic, the concern of MSME peoples for customers affected by the corona disease can be a tool to increase the selling value to customers. The attention and empathy given by MSME actors to customers who are their partners will make customers more loyal to MSME peoples who can understand the difficulties experienced by customers during the current corona pandemic.

The three fields of MSMEs in Medan City, in this case, are as follows:

1) Travel agent: MSME peoples in the field of Travel Agents in the city of Medan practically do not have any activity during this pandemic. Based on the results of interviews with MSME peoples in the Travel Agent field, they did CRM to maintain customer loyalty. There are several MSME peoples in the Travel Agent field who maintain communication with customers by sending messages to ask how their customers are doing. This is done as an effort to maintain good communication and relationships between the travel agent and its customers.

2) Convection: For MSME peoples in the field of convection in Medan City, this CRM activity has often been carried out since before the corona pandemic occurred. Various attempts to maintain good relationships with customers have been frequently made. These efforts include always providing the latest product information to customers, providing free delivery services, facilitating payment facilities and so on. This is a CRM activity for businesses in the Convection field in Medan City to maintain customer loyalty both before the pandemic and also during this corona pandemic.

3) Culinary: Culinary SMEs in Medan also carry out CRM activities to maintain customer loyalty. Ease of ordering, free shipping, ease of payment facilities are part of the efforts of SMEs in the culinary sector in Medan to maintain customer loyalty, especially during this corona pandemic. There are several MSME peoples in the culinary field in Medan City who provide new products for free to loyal customers to be able to try these latest products.

\section{CONCLUSION}

The results of the multiple linear regression above indicate that the independent variables, namely market access and business climate, have a positive effect on the dependent variable, namely business continuity. This means that the wider and easier market access and the better business climate will further increase business continuity. Meanwhile, the variable financial limitations has a negative effect on business continuity. This means that the more limited finances will reduce business opportunities to continue. In line with the results of previous research which state that external factors have a positive influence on the business continuity of MSMEs.

From interviews obtained from MSMEs in the fields of Culinary, Convection and Travel if MSMEs want to maintain business continuity, then they must maintain, update, and study in the fields of E-Commerce, digital marketing, Product and 
Service Quality Improvement, and Customer Relationship Marketing (CRM).

\section{REFERENCES}

[1] Gunartin, "Penguatan UMKM Sebagai Pilar Membangun Ekonomi Bangsa”. Eduka JurnalPendidikan, Hukum dan Bisnis, 1(V), 59-74. 2017.

[2] Ariani and M. Utomo, "Kajian Strategis Pengembangan Usaha Mikro Kecil dan Menengah (UMKM) di Kota Tarakan". Jurnal Organisasi dan Manajemen, 13(2), 99-118. 2017.

[3] H. Suandi and Y. Susilo, "Strategi Pengembangan Usaha Mikro, Kecil, dan Menengah di Provinsi Daerah Istimewa Yogyakarta". Jurnal Ekonomi Pembangunan, 12(1), 45-55. 2011.

[4] Sakur, "Kajian Faktor-faktor yang Mendukung Pengembangan Usaha Mikro, Kecil, dan Menengah: Studi Kasus di Kota Surakarta”. Jurnal Spirit Publik, 7(2). 2011.

[5] Irdayanti, "Peran Pemerintah Dalam Pengembangan UKM Berorientasi Ekspor: Studi Kasus Klaster Kasongan Dalam Rantai Nilai Tambah Global". Jurnal Transnasional, 3(2). 2012.

[6] A. Amri, "Dampak Covid-19 Terhadap UMKM di Indonesia", Jurnal Brand Volume 2 Nomer 1, hal 123-130. 2020.

[7] W. L. Hardilawati, "Strategi Bertahan UMKM di tengah Pandemi Covid-19”, Jurnal Akuntansi \& Ekonomika, Vol 10 Nomer 1, hal 89-98. 2020.

[8] A. K. Pakpahan, "Covid-19 dan Implikasi Bagi Usaha Mikro, Kecil dan Menengah", Jurnal Ilmiah Hubungan Internasional, 59-64. 2020.
[9] R. A. Belkaoui, Teori Akuntansi buku 1; Terjemahan Marwanta, Hanjanti Widyastuti, Heni Kurniawan dan Alia Ariesanti. Jakarta: Salemba Empat. 2000

[10] D. A. Wahyuningsih, Pengaruh Reputasi Auditor, Disclosure, Audit Client Tenure, Dan Ukuran Perusahaan Terhadap Opini Audit Going concern (Studi Empiris pada Perusahaan Manufaktur yang Terdaftar di BEI Tahun 2011-2013). Tesis, Universitas Muhammadiyah Surakarta.http://eprints.ums.ac.id/37163. 2015.

[11] P. Kotler and K. Keller, ManajemenPemasaran (12 ed.). Jakarta: Indeks. 2008.

[12] J. Romdonny and M. L. Rosmadi, "Pengaruh Merek, Promosi, dan Kualitas Produk Terhadap Keputusan Pembelian Bola Sepak". Jurnal Ikraith-Humaniora, 2(2), 82-89. 2018.

[13] J. Romdonny M. L. Rosmadi, "Manfaat E-Business Dalam Pemasaran Bola Sepak: Studi Empiris Pada PT. Sinjaraga Santika Sport (Triple S) Majalengka". Jurnal Industrial Services, 3(1b), 178-181. 2017.

[14] V. Egedius, Penerapan E-business di Indonesia. [Online]. Available at: http:// vandemegedius.co.id/2014/10/jurnal-penerapan-e-business. Accessed by 8 August 2020. 2014.

[15] K. C. Laudon and C. G. Traver, "E-Commerce 2014: Business, Technology and Society". Pearson Higher Ed. 2016.

[16] D. Purwana, R. Rahmi, and S. Aditya, "Pemanfaatan Digital Marketing Bagi Usaha Mikro, Kecil, Dan Menengah (UMKM) Di Kelurahan Malaka Sari, Duren Sawit". Jurnal Pemberdayaan Masyarakat Madani (JPMM), 1(1), pp.1-17. 2017. 